\title{
Speech Outcomes of Children with Cleft Palate Following Primary Palatal Surgery: A Retrospective Study
}

\author{
Seunghee $\mathrm{Ha}^{\mathrm{a}}$, Seungeun Jung ${ }^{\mathrm{b}}$, Heewon Moon ${ }^{\mathrm{b}}$, Kyungsuk Koh ${ }^{\mathrm{b}}$ \\ ${ }^{a}$ Division of Speech Pathology and Audiology, Audiology and Speech Pathology Research Institute, Hallym University, Chuncheon, Korea \\ ${ }^{b}$ Department of Plastic Surgery, Asan Medical Center, Seoul, Korea
}

Correspondence: Seunghee $\mathrm{Ha}, \mathrm{PhD}$ Division of Speech Pathology and Audiology, Audiology and Speech Pathology Research Institute, Hallym University, 1 Hallymdaehak-gil, Chuncheon 200-702, Korea

Tel: $+82-33-248-2225$

Fax: +82-33-256-3420

E-mail: shha@hallym.ac.kr

Received: July 2, 2014

Revised: August 12, 2014

Accepted: September 5, 2014
Objectives: This study aimed to investigate speech outcomes in a group of Korean children with cleft lip and/or palate following primary palatal surgery and to explore the relationship between cleft type and speech outcomes. Methods: The participants included 302 children with cleft palate who underwent primary palatal surgery between 2007 and 2012 and were seen for routine follow-up speech screening tests until 36 months of age. Retrospective analysis was performed using clinical records from the 36-month evaluation. General demographic information and data on cleft type, age of surgery, and other concomitant difficulties were obtained. Also, the following data were investigated: percent of children requiring secondary palatal surgery, percent who were enrolled in speech therapy, percent demonstrating significant hypernasality, percent indicating significant articulatory deficit, and percent demonstrating compensatory misarticulations. Results: Approximately $17 \%$ of the children had received secondary palatal surgery for velopharyngeal insufficiency and $48 \%$ of the children were enrolled in speech therapy. Chi-square analyses showed significant relationships between cleft type and variables on speech outcomes. Children with cleft lip and palate tended to show more significant hypernasality and articulatory deficits than children with cleft palate only. Conclusion: This study suggested that the majority of children with cleft palate demonstrated speech problems that require direct speech therapy. This study highlighted the importance of follow-up speech tests and speech intervention programs for children with cleft palate.

Keywords: Cleft palate, Speech outcomes, Cleft type, Primary palatal surgery
구개열은 대략 800-1,000명의 신생아 중 1명의 비율로 발생하는 대표적인 안면기형의 한 유형으로 유전 또는 환경적인 요인에 의해 발생하고 염색체 이상으로 인한 증후군의 신체적 증상 중 하나로 서 나타나기도 한다(Peterson-Falzon, Hardin-Jones, \& Karnell, 2001). 선천적인 구강과 연인두 구조의 결함으로 인해 구개열을 가 지고 태어난 아기들은 출생 직후부터 섭식상의 어려움을 보이고, 일반적으로 생후 12 개월에 실시되는 구개성형술을 비롯하여 청소 년기까지 치아안면 골격상의 문제를 교정하기 위해 상악골교정술, 골이식술(bone grafting) 등 여러 가지 외과적 수술과 교정을 경험 하게 된다. 또한 선천적인 구강과 비강내 근육의 결함으로 인해 잦
은 중이염을 보이고 많은 수의 아동들은 초기 말-언어발달상의 지 연을 보이고, 과다비성, 보상조음과 같은 구개열로 인한 특유의 말 장애를 보이게 된다. 입술 주변의 흥터, 부정교합과 같은 외모상의 문제와 말-언어상의 문제로 인해 부정적인 자아상을 발달시킬 수 있고 학령기 전까지 말-언어문제를 적절하게 치료하지 않는다면 이 차적으로 사회성, 정서, 학습상의 문제들을 보여 성인기에 이르기 까지 지속적인 어려움을 일으킬 수 있다. 반면에 시기적절하고 효과 적인 치료를 학령전기에 받는다면 학령기 이후에는 언어치료와 큰 외과적 수술과 같은 부가적인 의료서비스의 필요성 없이 정상적인 삶을 영위하게 된다. 이러한 시기적절하고 효과적인 의료서비스의 
중요성으로 인해 미국 등 서구 선진국에서는 지난 50 여 년 동안 구 개열 아동을 위한 의료서비스 개선을 위해 지속적인 노력을 기울 여 오고 있다(Hardin-Jones \& Jones, 2005). 그러한 노력의 결과로 서 수술시기, 수술법, 다학제적 팀 접근법(multidisciplinary team approach), 조기 중재 제공 면에서 의료서비스의 향상과 개선이 일 어났다(LaRossa, 2000; McWilliams et al., 1996; Peterson-Falzone et al., 2001). 대표적으로 변화를 가져온 부분은 수술시기로서 과거 에는 18 개월 이후에 보편적으로 시행되던 1차 구개성형술(primary palatoplasty)이 정상적인 말 발달을 촉진하고 보상조음의 출현을 최소화하기 위해서는 조기에 실시되어야 한다는 언어병리학자와 언어치료사들의 주장으로 그 시기가 앞당겨져 현재는 생후 9-12개 월에 보편적으로 실시되고 있다(Chapman et al., 2008).

미국과 영국을 비롯한 유럽의 여러 국가에서는 구개열 아동을 위한 점진적인 의료서비스 개선과 함께 많은 연구들이 1 차 구개성 형술 이후 여전히 연인두 부위의 구조적인 문제를 보여 2 차 구개성 형술을 필요로 하는 아동들의 출현율을 살펴보거나 1 차 수술 이 후 구개열 아동들의 말 산출 능력을 살펴봄으로써 구개열 아동들 을 위한 치료법의 효과를 점검하고 있다(Bearn et al., 2001; Chapman et al., 2008; Hardin-Jones \& Jones, 2005; Inman, Thomas, Hodgkinson, \& Reid, 2005; Jackson et al., 2013; Karling, Larson, Leanderson, \& Henningsson, 1993; Phua \& de Chalain, 2008; Webb, Watts, Read-Ward, Hodgkins, \& Markus, 2001). 예를 들면 Jackson 등(2013)의 연구는 미국 필라델피아 아동병원에서 정상적인 재 배치를 강조하면서 수술 후 입천장이 길어지는 효과가 있는 Furlow double-opposing Z 수술법을 1 차 구개성형술로 30 년 동안 시행한 후 연인두 형성부전(velopharyngeal insufficiency)으로 인한 2차 구개성형술을 필요로 하는 아동의 수와 과다비성 정도를 조사하 였다. 연구결과 1 차 구개성형술을 받은 아동 중 오직 $5.1 \%$ 만이 2 차 구개성형술이 추가적으로 필요했고 $17.3 \%$ 만이 치료가 필요한 유의 미한 과다비성을 보인다고 보고하였다. 그리고 연구자들은 그들이 시행하는 수술법과 구개열 팀 접근법을 통해 많은 수의 구개열 아 동이 1 차 구개성형술 이후 안정적이고 정상적인 말 산출 능력을 보 인다고주장하였다.

국내의 구개열 아동을 위한 의료서비스 면에서도 수술시기와 수 술법은 국외의 연구 결과와 치료 프로토콜을 토대로 변화가 이루 어져 오고 있다. 하지만 이러한 의료서비스의 향상과 개선이 구개 열 아동의 삶의 질, 특히 말-언어발달과 습득과 관련해서 어떠한 영 향을 주었는지에 대해 대단위 객관적인 자료를 바탕으로 실제적으 로 검증하는 연구는 부족한 상태이다. 최근 일반아동과 비교하여 구개열 아동의 초기 발성과 말소리 발달을 살펴보거나 초기 표현어
휘의 특성을 자세히 살펴보는 연구(Ha, 2014; Kim \& Ha, 2013; Moon $\& \mathrm{Ha}, 2012)$ 가 지속적으로 이루어지고 있으나 주로 소규모 구개열 아동의 초기 말 발달을 살펴보는 데 국한되어 있다. 1 차 구개성형술 이후 구개열 아동의 말-언어발달은 일반적으로 어떻게 이루어지고 있는지와 구개열 아동 중 얼마나 지속적이고 부가적인 중재 서비스 를 요하는 말 문제를 보이는지에 대해 살펴보면서 지속적인 말 문 제와 밀접한 관련이 있는 요인에 대한 역학조사는 최근까지는 아주 부족한 실정이다.

문헌에서 1 차 구개성형술 이후 구개열 아동의 말 산출능력에 영 향을 끼치는 요인으로서 일반적으로 논의되는 것에는 구개열 유형, 구개성형술 방법과 시기, 중이염 여부, 부모교육을 통한 조기중재 가 있다(Albery \& Grunwell, 1993; Chapman et al., 2008; Ha, 2011, 2013; Hardin-Jones, Brown, Van Demark, \& Morris, 1993; Inman et al., 2005; Jackson et al., 2013; LaRossa, 2000; McWilliams et al., 1996; Peterson-Falzone, 1990; Phua \& Chalain, 2008; Riski \& DeLong, 1984; Van Demark \& Hardin, 1985). 여러 요인 중 구개성형 술 방법과 시기는 보다 더 체계적이고 지속적인 연구가 필요하지만 선천적인 결함 정도와 패턴을 고려하면서 구개올림근의 정상적인 재배치를 강조하는 수술법이 효과적이고 생후 12 개월 이전에 1 차 구개성형술을 실시하는 것이 말 발달에 보다 더 긍정적이라는 것에 는 의견의 일치를 보이고 있다. 중이염 여부와 관련해서는 말 습득 이 활발하게 이루어지는 시기 동안의 만성적인 중이염은 말-언어발 달에 부정적인 영향을 준다는 결과가 지배적이고 조기 언어중재를 받은 아동들이 보다 더 긍정적인 말 발달 양상을 보인다는 연구결 과가 일반적이다. 반면에 구개열 유형에 따라 1 차 구개성형술 이후 지속적으로 보이는 연인두 형성부전이나 말 문제 정도를 살펴보는 연구들은 서로 다소 상이한 연구결과를 제시하고 있다. 예를 들어 Hardin-Jones 등(1993)에서는 일측성 또는 양측성 구순구개열 아 동이 연구개 또는 경구개 파열을 동반한 구개열 아동들과 비교해 보다 더 많은 수가 연인두 형성부전을 보이고 말 문제의 심각도도 높다고 보고하였다. 반면에 Hardin-Jones, Chapman과 Schulte (2003) 연구는 구개열 아동이 구순구개열 아동보다 보상조음 산출 빈도가 낮고 구강 앞쪽소리를 더 많이 산출하는 경향은 있지만 구개열 유 형에 따라 초기 발성과 말소리 산출에는 통계적으로 유의미한 차 이가 나타나지 않았다고 보고하면서 더 많은 아동들을 대상으로 추후 지속적인 연구가 필요하다고 제안하였다.

따라서 본 연구에서는 구개열 유형별 발생 비율과 수술시기와 같 은 구개열 관련 정보와 1 차 구개성형술 이후 구개열 아동이 어떠한 말 발달을 보이는지 살펴보고자 하였다. 이를 위해 1 차 구개성형술 이후 생후 36 개월 정도에 이루어진 추적 말-언어선별검사결과를 토 
대로 2차 구개성형술, 언어치료와 같은 부가적인 중재 서비스를 받 은 아동의 비율과 유의미한 과다비성과 조음 문제를 보이는 아동 의 비율이 어떠한지 살펴보았다. 또한 구개열 유형에 따라 1 차 구개 성형술 이후 아동의 말 산출 능력이 유의미하게 차이를 보이는지 살펴보았다.

\section{연구 방법}

\section{대상자}

본 연구는 자료수집이 이루어진 서울아산병원 임상연구심의위 원회로부터 임상연구 계획심의(IRB)를 걸쳐 승인을 받고 실시되었 다. 연구는 2007년부터 2012년 서울아산병원 구개열 클리닉에서 1 차 구개성형술을 받고 이후 3-6개월 단위로 실시되는 말-언어선별 검사에 생후 36 개월까지 정기적으로 참여한 아동들을 대상으로 하였다. 자료 수집이 이루어진 구개열 클리닉에서는 본 연구의 제 4 저자가 구개열 아동의 구강과 연인두 기제의 선천적인 결함 정도와 유형에 따라 Furlow double opposing Z-plasty, two-flap palatoplasty, intravelar veloplasty, von Langenbeck flaps 등의 수술기법 중 하나를 선택하여 1 차 구개성형술을 시행하고 있다. 그리고 일반 적으로 1차 구개성형술 이후 30-36개월까지 정기적인 추적평가 (follow-up test)를 통해 발달상황을 지켜보다가 아동의 말 발달 지 연이나 문제가 뚜렷해지는 30-36개월에 실시되는 평가자료를 토대 로 2 차 구개성형술, 언어심화평가, 또는 직접적인 언어치료를 권고 하고 있다. 36 개월 정도에 아동이 생활연령에 적절한 말 발달을 이 루고 있으며 특이사항이 없다고 판단될 경우에는 정기적인 말-언어 선별검사를 종료한다. 1 차 구개성형술 이후 생후 36 개월까지 정기 적으로 말-언어 선별검사에 참여하지 않아 부분적인 자료만 있는 경우에는 본 연구 대상자에서 제외하였다.

생후 36 개월 선별검사 결과 자료를 토대로 대상자를 선정한 결과 총 333명(남 173명, 여 160명, 평균연령 6세 2개월)이 포함되었다. 이 중 증후군(syndrome)을 동반한 구개열 아동이 31명(남 17명, 여 14 명, 평균연령 6 세 1 개월)인 것으로 나타났으며 총 15 가지 증후군이 확인되었으며 증후군 유형 중 입천장-심장-얼굴 증후군(velocardiofacial syndrome)이 9명으로 가장 높게 나타났다. 증후군을 동 반한 구개열 아동의 경우 단순 구개열 아동의 말-언어발달 양상과 심각도 면에서 다르고 일반적으로 신체, 인지, 정서 면에서도 다양 한 부가적인 문제를 보이기 때문에 본 연구에서는 증후군을 동반 한 구개열 아동을 제외한 생후 36 개월 이상의 302 명(남 156 명, 여 146 명, 평균연령 6 세 3 개월)의 자료만을 분석에 포함시켰다.

\section{연구 절차}

본 연구는 생후 36 개월에 실시된 선별검사결과와 병원 진료 기 록을 토대로 후향적으로 실시되었다. 생후 36 개월에 실시된 선별검 사결과를 기준으로 자료 분석을 실시한 이유는 그 시기가 되면 아 동의 직접적인 말 산출을 바탕으로 직접적인 평가가 가능하고, 말언어발달 상황에 대한 아동 간 개인차가 줄어 2 차 수술과 언어치료 등의 추후 필요한 부가적인 서비스에 대한 임상적 판단이 비교적 명확해지기 때문이다. 또한 1 차 구개성형술 이후 말 산출 능력을 살 펴보는 대부분의 연구(Chapman et al., 2008; Hardin-Jones et al., 1993; Hardin-Jones \& Jones, 2005)에서도 생후 36개월 또는 그 이 후에 실시된 평가결과를 토대로 보고하고 있다. 자료수집이 이루어 진 구개열 클리닉에서의 말-언어선별검사는 2008 년 이래로 제 1 저 자와 제 2 저자가 함께 듣기 훈련과 문헌조사를 바탕으로 한 논의 과 정을 통해 말 평가과제와 절차를 정립시켜 나갔다. 말-언어선별검 사에서는 표현어휘수, 말 명료도, 언어이해 정도, 다른 동반문제 여 부 등 일상생활에서 아동이 보이는 의사소통 능력에 대해 보호자 에게 질문을 하여 정보를 수집하였다. 또한 우리말조음음운검사 (U-TAP; Kim \& Shin, 2004)와 구강 자음으로만 구성된 문장 따라 말하기 과제, 1-2분 정도의 아동과의 대화를 통해 아동의 직접적인 반응을 유도하여 아동의 발화를 비디오 녹화 및 오디오로 녹음하 여 수집하였다. 수집한 아동의 말자료를 바탕으로 7점 등간척도(1 점 $=$ 정상; 2 점 $=$ 미비 $($ minimal); 3 점 $=$ 경도; 4 점 $=$ 경중도; 5 점 $=$ 중 도; 6 점 $=$ 심중도; 7 점 $=$ 심도)를 이용하여 과다비성과 조음 문제의 심각도에 대해 현장에서 제 2 저자가 제 1 저자와 함께 또는 독립적으 로 평가하였다. 본 연구에서 사용한 7점 등간척도를 이용한 과다비 성과 조음의 심각도 평가는 구개열 화자의 말 산출 능력을 보고할 때 사용할 수 있는 보편적인 지표를 제안한 Henningsson 등(2008) 연구를 토대로 기준을 정하였다. 조음 능력 수준에 관해서는 Henningsson 등(2008)의 연구 외에 자음정확도와 비교하여 언어치료 사가 심각도 등급을 주관적으로 평가하는 것에 대해 조사한 Shriberg와 Kwiatkowski (1982)의 연구도 참조하였다. 또한 문헌조사와 더불어 제 1 저자와 제 2 저자가 구개열 클리닉에서 구개열 아동들의 전반적인 조음 능력 수준과 특징을 관찰하면서 논의를 통해 각 등 급기준에 대한 조작적 정의를 설정하여 평가하였다(Appendix 1). 조음 능력과 관련해서 아동이 구개열과 관련된 특징적인 조음 오 류인 보상조음을 보일 경우 따로 기재하고 보상조음을 보이는 음소 유형을 구체적으로 기록하였다. 또한 아동이 비누출(nasal emission)을 보일 경우 동반되어 산출되는 음소 유형과 특징(소음 동반) 에 대해 자세히 기술하였다. 


\section{자료 분석}

아동의 진료 기록을 토대로 아동의 성별, 생년월일, 구개열 유형, 동반 증후군 유무, 1 차 구개성형술 시기, 다른 수술적 처치 여부, 2 차 구개성형술 또는 언어치료 여부 등에 대해 조사하였다. 2차 구개성 형술과 언어치료 여부는 생후 30-36개월에 실시되어진 선별검사결 과를 토대로 주로 결정되고 진행되기 때문에 두 항목에 관해서는 36 개월 이후 아동의 외래 진료 기록을 추가로 살펴보았다. 또한 아 동이 구개열 클리닉 외에 다른 과 소속 언어치료실에서 심화언어평 가를 받았고 결과가 진료 기록에 있다면 참조하였다. 말 선별검사 결과를 토대로 1) 과다비성 여부 및 심각도 2) 조음 문제 여부 및 심 각도 3) 보상조음 산출 여부 4) 표현언어 지연 여부 5) 기타 동반 의 사소통 장애 여부를 조사하였다. 본 연구의 자료수집이 이루어진 클리닉에서는 조음과 과다비성 문제와 관련하여 7점 등간척도 상 에서 경중도에 해당하는 4점 이상의 심각도를 보일 경우 일반적으 로 언어치료 또는 2 차 구개성형술이 필요하다고 판단되어 권고된 다. 대다수의 구개열 아동이 일반아동과 비교해 2점(미비) 이상의 과다비성 문제나 지연된 조음발달을 보이고 경도 미만의 조음과 공 명 문제를 말 장애로 판단하는 것에는 과잉 진단의 위험이 있다. 또 한 1 차 구개성형술 이후 말 산출 능력을 살펴본 선행연구들에서도 모두 경도 이하의 과다비성과 조음 문제는 사회적으로 용인되는 말(acceptable speech)로 간주하여 경중도 또는 중도 이상의 심각도 를 보이는 경우만을 주로 보고하였다(Hardin-Jones \& Jones, 2005; Jackson et al., 2013). 따라서 본 연구에서는 언어치료와 2 차 수술이 필요하다고 명확하게 판단되는 경중도인 4점 이상의 조음 및 공명 문제만을 분석에 포함하였다. 표현언어지연 여부도 선별평가만 실 시하고 표준화된 언어공식검사나 자발화 분석을 실시한 것이 아니 기 때문에 30-36개월에 표현어휘가 10-20개 미만, 한 낱말 수준으 로만 표현하는 뚜렷한 언어발달지연을 보여 심화평가가 필요한 아 동만을 표현언어지연을 보이는 것으로 간주하였다.

Table 1. Types of cleft palate and age of participants at primary palatal surgery

\begin{tabular}{lcc}
\hline Cleft type & $\mathrm{N}(\%)$ & Age at surgery $(\mathrm{mo})$ \\
\hline Overt cleft palate & & 12.09 (SD $=4.82)$ \\
UCLP & $78(25.83)$ & \\
BCLP & $38(12.58)$ & \\
CP & $160(52.98)$ & \\
SMCP & $26(8.61)$ & $47.36(S D=36.73)$ \\
Total & $302(100)$ & \\
\hline
\end{tabular}

$\mathrm{UCLP}=$ unilateral cleft lip and palate; $\mathrm{BCLP}=$ bilateral cleft lip and palate; $\mathrm{CP}=\mathrm{cleft}$ palate; $\mathrm{SMCP}=$ submucous cleft palate

\section{신뢰도}

말 선별평가 동안 수집된 연구대상자의 음성샘플 중 약 $10 \%$ 를 무선으로 추출하여 7점 등간척도를 이용한 조음 및 과다비성 평가 에 대한 제 1 저자와 제 2 저자간 평가자간 신뢰도를 Spearman 순위 상관계수(Spearman rank correlation coefficient)을 이용하여 구 하였다. 신뢰도 분석결과 조음 평가는 Spearman 순위상관계수 $\rho$ $=.811$ 이고 과다비성 평가는 $\rho=.839$ 로 나와 모두 유의수준 .01 미 만으로 통계적으로 유의한 상관관계를 보이는 것으로 나타났다.

\section{통계처리}

구개열 유형별 아동, 1 차 구개성형술 이후 2 차 구개열성형술 또는 언어치료를 받은 아동 수, 경중도 이상의 조음과 과다비성 문제, 보 상조음을 보이는 아동의 수를 조사하여 전체 연구대상자 중 각 항 목이 차지하는 비율을 살펴보았다. 구개열 유형에 따른 말 산출 능 력을 살펴보고자 구개열 유형을 독립변인으로 2 차 구개성형술, 언 어치료를 받은 아동 비율, 경중도 이상의 조음문제와 과다비성을 보이는 아동 비율, 보상조음을 보이는 아동 비율을 종속변인으로 카이제곱 검정을 실시하였다. 본 연구의 통계처리는 PASW 18.0을 이용하였으며, 모든 유의수준은 $p<.05$ 로 설정하였다.

\section{연구 결과}

\section{구개열 유형과 수술 시기}

구개열 유형을 양측성 구순구개열, 일측성 구순구개열, 구개열, 점막하 구개열로 분류하여 본 연구에 최종적으로 포함된 302 명 아 동을 대상으로 각 구개열 유형별 차지하는 비율을 살펴보았다(Ta-

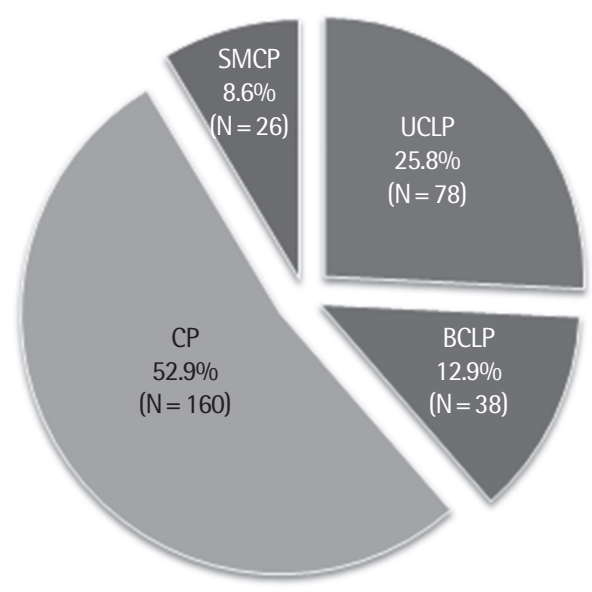

Figure 1. Percentage of each cleft palate type. UCLP=unilateral cleft lip and palate; $\mathrm{BCLP}=$ bilateral cleft lip and palate; $\mathrm{CP}=$ cleft palate; $\mathrm{SMCP}=$ submucous cleft palate. 
ble 1, Figure 1). 구개열 유형 중 입술 파열 없이 경구개/연구개에만 파열이 있는 구개열 유형이 $52.98 \%$ 으로 가장 높은 비율을 차지하 였고 그 다음으로 일측성 구순구개열(25.83\%), 양측성 구순구개열 (12.58\%), 점막하 구개열(8.61\%) 순으로 나타났다. 26명의 점막하 구개열 아동 중 8 명은 구순열도 가지고 태어나 이에 대한 수술 교정 을 받은 것으로 나타났다. 점막하 구개열은 파열이 명확하게 드러 나는 구개열 아동(overt cleft palate)과 비교해 발견이 늦어지고 말 문제 여부와 심각도에 따라 수술시기가 정해지기 때문에 두 유형을 나누어 1 차 구개성형술이 이루어진 시기를 살펴보았다. 일반 구개 열 아동의 경우 평균 생후 12.09 개월에, 점막하 구개열 아동은 평균 47.36 개월에 구개열 교정술을 받은 것으로 나타났다.

\section{1차 구개성형술 이후 말 문제}

1 차 구개성형술 이후 36 개월에 실시된 말-언어선별검사 결과를 정리하면 Table 2 와 같다. 먼저 1 차 구개성형술을 받고 36 개월까지 말-언어선별검사를 받은 아동 중 38 명(12.58\%)만이 정상적인 말-언 어발달을 이루었다고 판단되어 2 차 구개성형술이나 언어치료의 추 가적인 권고 없이 수술 후 추적평가를 종결한 것으로 나타났다. 나 머지 아동은 직접적인 언어치료나 2차 구개성형술을 권고받았거

Table 2. Results of speech-language screening tests following primary palatal surgery

\begin{tabular}{lr}
\hline Result & $\mathrm{N}(\%)$ \\
\hline Normal speech \& language development & $38(12.58)$ \\
Secondary palatal surgery & $52(17.21)$ \\
Speech therapy & $145(48.01)$ \\
Hypernasality greater than mild to moderate & $92(30.46)$ \\
Articulatory deficits greater than mild to moderate & $171(56.62)$ \\
Compensatory articulation & $125(41.39)$ \\
Expressive language disorders & $50(16.56)$ \\
Other conditions & $26(8.61)$ \\
Total & $302(100)$ \\
\hline
\end{tabular}

나 경미한 말-언어문제를 보여 추적평가를 종료하지 않고 발달상황 을 지켜보는 것으로 권고받았다.

1 차 구개성형술 이후에도 연인두 부위에 구조적인 문제를 지속 적으로 보여 2 차 구개성형술을 받은 아동은 52 명으로 전체 연구대 상자 중 $17.21 \%$ 인 것으로 나타났고 평균 $65.25(\mathrm{SD}=34.15)$ 개월에 2 차 수술을 받은 것으로 나타났다. 또한 1차 구개성형술 이후 보상조 음 또는 말 발달 지연 등의 말-언어 문제를 보여 언어치료를 받은 아 동은 145명(48.01\%)으로 나타났다. 선별평가에서 경중도인 4 등급 이상의 과다비성을 보인 아동은 92 명(30.46\%)이었고 4 등급 이상의 조음 문제를 보인 아동은 171 명(56.62\%)으로 나타났다. 구개열로 인한 보상조음을 보인 아동은 125 명(41.39\%)으로 나타났다. 또한 표현어휘의 제한으로 또래 일반아동과 비교해 뚜렷하게 표현언어 발달 지연을 보이는 아동은 50명(16.56\%)으로 나타났고 그 외에 선 별검사 시 확인되었거나 진료 기록에 기재된 같은 병원 다른 과 소 속 언어치료실에서 실시된 언어심화평가 결과를 토대로 확인된 유 창성장애, 말 실행증 등의 동반 문제를 보이는 아동이 26명(8.61\%) 인 것으로 나타났다.

\section{구개열 유형에 따른 말 문제}

구개열 유형에 따른 말 산출 능력을 살펴보고자 카이제곱 검정 을 실시한 결과는 Table 3 과 같다. Figures 2 와 3 은 구개열 유형별로 2차 구개성형술과 언어치료를 받거나 받지 않은 아동의 비율을 나 타낸 것이다. 분석 결과 보상 조음을 보이는 아동의 비율 항목을 제 외한 나머지 종속변인들은 구개열 유형에 따라 유의미한 차이를 보 이는 것으로 나타났다. 먼저 구개열 유형에 따라 2 차 구개성형술을 받은 아동의 비율이 유의미한 차이를 보였는데 $\left(\chi^{2}=15.03, p=.002\right)$, 구개열과 점막하 구개열 유형보다 일측성 또는 양측성 구순구개열 아동들이 2 차 구개성형술을 필요로 하는 경우가 더 높은 것으로 나타났다. 언어치료를 필요로 하는 아동 비율도 구개열 유형에 따 라 유의미한 차이를 보였는데 $\left(\chi^{2}=14.49, p=.002\right)$, 일측성 또는 양

Table 3. Percentage of children who received secondary palatal surgery and speech therapy, demonstrated significant hypernasality, or had articulatory deficits and compensatory articulation according to the types of cleft palate

\begin{tabular}{lccrrrrr}
\hline Result & UCLP & BCLP & CP & SMCP & Total & \multicolumn{1}{c}{$\chi^{2}$} & $p$ \\
\hline Total & $78(25.8)$ & $38(12.9)$ & $160(52.9)$ & $26(8.6)$ & $302(100)$ & & \\
2nd palatal surgery & $20(25.6)$ & $12(31.6)$ & $18(11.3)$ & $2(7.7)$ & $52(17.2)$ & 15.03 & .002 \\
Speech therapy & $43(55.1)$ & $24(63.2)$ & $61(38.1)$ & $17(65.4)$ & $145(48.0)$ & 14.49 & .002 \\
Hypernasality & $39(5.0)$ & $13(34.2)$ & $32(20.0)$ & $8(30.8)$ & $92(30.5)$ & 22.58 & $<.001$ \\
Articulatory deficits & $51(6.5)$ & $27(71.1)$ & $74(46.3)$ & $19(73.1)$ & $171(56.6)$ & 15.53 & .001 \\
Compensatory articulation & $37(4.7)$ & $19(50.0)$ & $57(35.6)$ & $12(46.2)$ & $125(41.4)$ & 4.77 & .189 \\
\hline
\end{tabular}

Values are presented as number $(\%)$.

$\mathrm{UCLP}=$ unilateral cleft lip and palate; $\mathrm{BCLP}=$ bilateral cleft lip and palate; $\mathrm{CP}=$ cleft palate only; $\mathrm{SMCP}=$ submucous cleft palate. 


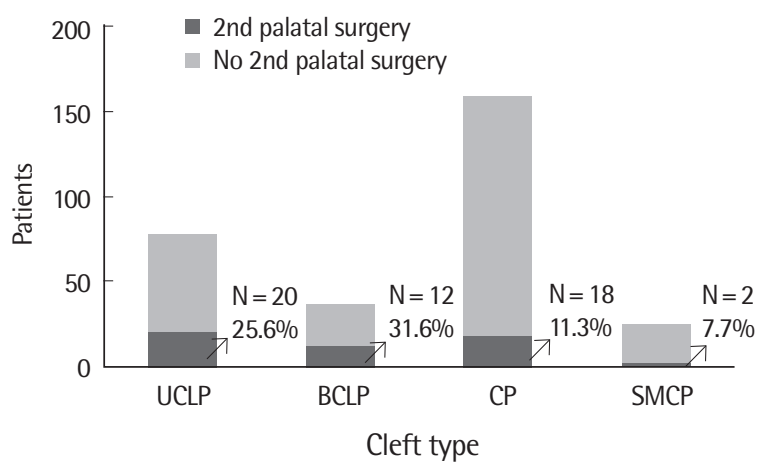

Figure 2. Percentage of secondary palatal surgery according to the types of cleft plate. UCLP= unilateral cleft lip and palate; BCLP=bilateral cleft lip and palate; $\mathrm{CP}=$ cleft palate only; $\mathrm{SMCP}=$ submucous cleft palate.

측성 구순구개열 아동과 점막하 구개열 아동 중 $50 \%$ 이상이 언어 치료를 받고 있거나 받은 것으로 나타났다. 경중도 이상의 과다비 성 문제를 보이는 아동 비율도 구개열 유형에 따라 유의미하게 달 랐다 $\left(\chi^{2}=22.58, p<.001\right)$. 양측성 구순구개열 아동과 점막하 구개 열 아동이 상대적으로 높은 비율로 과다비성 문제를 보이는 것으 로 나타났다. 마찬가지로 경중도 이상의 조음 문제를 보이는 아동 비율도 구개열 유형에 따라 차이를 보였다 $\left(\chi^{2}=15.53, p=.001\right)$. 점 막하 구개열 또는 양측성 구순구개열 아동 중 $70 \%$ 이상이 조음 문 제를 보이는 것으로 나타났고 구개열 아동은 $46.3 \%$ 가 조음 문제를 보이는 것으로 나타났다.

\section{논의 및 결론}

본 연구에서는 2007년부터 2012년 사이 1차 구개성형술을 받고 생후 36 개월까지 정기적인 말-언어선별검사를 받은 302 명의 아동 을 대상으로 구개열 유형별 비율과 수술시기를 살펴보았고, 2 차 구 개성형술 또는 언어치료를 받은 아동의 비율과 유의미한 과다비성 과 조음 문제를 보이는 아동의 비율을 통해 말 발달 상황을 살펴보 았다. 먼저 구개열 유형별 아동 비율을 살펴본 결과 입술 파열 없이 경구개/연구개에만 파열이 있는 구개열 유형이 $52.98 \%$ 으로 가장 높 은 비율을 차지하였고 그 다음으로 일측성 구순구개열(25.83\%), 양 측성 구순구개열(12.58\%), 점막하 구개열(8.61\%) 순으로 나타났다. 이러한 결과는 구개열 유형별 발생 비율을 살펴본 기존 문헌과는 차이가 있는데 문헌에서는 인종과 성별에 따라 다소 차이가 있지 만 일반적으로 구순구개열이 구순열과 구개열보다 발생 비율이 더 높다고 보고하고 있다(Peterson-Falzon et al., 2001). 예를 들어 Fogh-Anderson (1942)은 덴마크에서 태어난 구개열 인구를 토대 로 유형별 발생률을 살펴보았는데 구순열이 $25 \%$, 구순구개열은

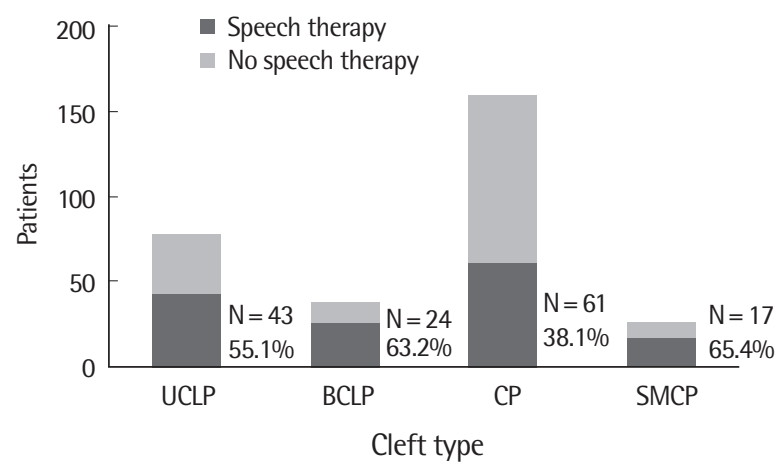

Figure 3. Percentage of children who have received speech therapy according to the types of cleft palate. UCLP = unilateral cleft lip and palate; BCLP= bilateral cleft lip and palate; $C P=$ cleft palate only; $\mathrm{SMCP}=$ submucous cleft palate.

$50 \%$, 구개열이 $25 \%$ 를 차지한다고 보고하였다(as cited in PetersonFalzon et al., 2001). 본 연구에서 나타난 구개열 유형별 비율은 자연 스러운 발생률을 반영한다기보다는 출생 전 태내에서 입술 주변의 기형을 확인하는 것이 가능한 초음파 산전검사의 영향으로 입술 파열을 동반한 구순구개열의 발생률이 과거 연구와는 달리 감소했 다고추정해볼수 있다.

발견이 일반적으로 늦어 수술시기가 늦어지는 점막하 구개열을 제외한 구순구개열 또는 구개열 아동은 평균 생후 12.09 개월에 1 차 구개열 교정술을 받은 것으로 점막하 구개열 아동은 평균 47.36개 월에 구개열 교정술을 받은 것으로 나타났다. 1 차 구개성형술 이후 36 개월에 실시된 말-언어선별검사결과와 외래 진료기록을 토대로 연인두 형성부전 또는 말 문제 발생률을 살펴본 결과 전체 연구대 상자 중 $17.21 \%$ 가 1 차 구개성형술 이후에도 연인두 부위에 구조적 인 문제를 지속적으로 보여 2차 구개성형술을 받은 것으로 나타났 다. 그리고 연구대상자의 $30.46 \%$ 가 추가적인 중재 서비스를 통해 소거시켜야 할 정도의 경중도 이상의 과다비성을 보이는 것으로 나 타났다. 두 항목에 대한 비율상의 차이는 경중도 이상의 과다비성 을 보이는 아동 중 절반 정도는 2 차 구개성형술을 통해 문제를 해결 하고 나머지는 그 심각도가 상대적으로 낮고 조음 문제를 동반하 여 수술적 중재보다는 언어치료를 통해 문제를 해결하도록 권고받 은 것과 관련이 있다. 1 차 구개성형술 이후 연인두 형성부전의 출현 율을 살펴본 선행연구들은 $9 \%$ 대에서부터 높게는 $30 \%$ 이상을 보고 하고 있다(Bearn et al., 2001; Chapman et al., 2008; Hardin-Jones \& Jones, 2005; Inman et al., 2005; Jackson et al., 2013; Karling et al., 1993; Phua \& de Chalain, 2008; Webb et al., 2001). 이러한 상이 한 연구결과는 연구마다 서로 다른 기준으로 연인두 형성 부전을 정의하여 살펴본 것과 관련이 있을 수 있는데 어떤 연구는 2 차 구개 성형술이 필요한 경우만 포함시키기도 하고 어떤 연구는 과다비성 
심각도를 기준으로 분석하여 다양한 경향을 보였다. 또한 연인두 형성부전은 수술시기, 수술법, 선천적인 결함 정도 등 다양한 변인 에 의해서 영향 받기 때문에 이에 대한 관련변인을 찾는 보다 더 자 세한 연구가 필요할 것으로 생각된다.

언어치료력과 관련하여 전체 연구대상자 중 $48.01 \%$ 가 1 차 구개 성형술 이후 보상조음 또는 말 발달 지연 등의 말-언어 문제를 보여 언어치료를 받은 것으로 나타났다. 또한 $56.62 \%$ 의 구개열 아동이 경중도 이상의 조음 문제를 보인 것으로 나타났고, $41.39 \%$ 의 아동 이 구개열로 인한 보상조음을 보인 것으로 나타났다. 또한 표현어휘 의 제한으로 또래 일반아동과 비교해 뚜렷하게 표현언어발달 지연 을 보이는 아동은 $16.56 \%$ 으로 나타났고 그 외에 유창성장애, 말 실 행증 등의 동반 문제를 보이는 아동이 $8.61 \%$ 인 것으로 나타났다. 이 러한 연구결과는 구개열 아동을 위한 전반적인 서비스가 향상을 보여 1 차 구개성형술 이후 지속적인 말 문제를 보이는 아동의 비율 이 과거보다는 점진적으로 감소하는 추세이지만 여전히 많은 수의 구개열 아동들이 1 차 구개성형술 이후 보상조음과 말 발달 지연을 보여 이에 대한 전문적인 언어치료 서비스를 필요로 한다는 것을 제시하고 있다. 본 연구결과와 비슷하게 212 명의 학령전기의 구개 열 아동의 말 산출 능력을 살펴본 Hardin-Jones과 Jones (2005)은 연구 대상자 중 $37 \%$ 가 유의미한 과다비성을 보이거나 연인두 형성 부전으로 2 차 수술을 받았고 $68 \%$ 의 아동이 언어치료를 이전에 받 았거나 받고 있다고 보고하면서 1 차 구개성형술 이후 정기적인 말 평가와 중재의 중요성을 강조하였다.

본 연구에서는 선행연구에서 구개열 아동의 말 발달에 중요 요인 으로서 제기되는 구개열 유형과 1차 구개성형술 이후 아동의 말 산 출 능력과의 관계도 살펴보았다. 연구결과 구개열 유형은 보상 조 음을 보이는 아동 비율을 제외한 나머지 살펴본 종속변인과 유의 미한 관계가 있는 것으로 나타났다. 전반적으로 구개열 아동보다 일측성 또는 양측성 구순구개열 아동들이 2 차 구개성형술과 언어 치료를 받은 비율이 높고 중재가 필요한 경중도 이상의 조음과 과 다비성 문제를 보이는 비율도 상대적으로 더 높게 나타났다. 이러 한 연구결과는 연구마다 그 결과가 다소 다르지만 보다 더 많은 수 의 연구에서 구순구개열 아동이 구개열 아동보다 더 심각한 말 문 제를 보인다고 제안한 결과를 지지하는 것이다(Albery \& Grunwell, 1993; Hardin-Jones et al., 1993; Peterson-Falzone, 1990; Riski \& DeLong, 1984; Van Demark \& Hardin, 1985). 구개열 유형이 구 강과 연인두 기제의 선천적인 결함 정도와 완전히 일치하는 것은 아니지만 구순구개열이 구개열보다 선천적인 결함 정도가 일반적 으로 더 심하다고 할 수 있다. 이러한 점을 고려한다면 구개열 유형 에 따른 본 연구결과는 구강과 연인두 부위의 선천적인 결함 정도
와 어느 정도 관련이 있다고 해석해 볼 수 있다. 반면에 상대적으로 선천적인 결함 정도가 낮은 점막하 구개열 아동도 높은 비율로 언 어치료력과 조음 및 과다비성 문제를 보였는데 이 점은 다른 구개 열 유형과 비교해 진단과 수술적 중재를 늦게 받은 것과 관련이 있 다. 본 연구에서의 점막하 구개열 아동은 평균 47 개월에 구개성형 술을 받았고 늦게는 만 7-9세 이후에도 수술적 중재를 받은 아동도 포함되어 수술 이후에도 상대적으로 지속적인 말 문제를 보이는 아동이 많은 것으로 나타났다. 이러한 점은 점막하 구개열 여부를 가능한 조기에 발견하여 수술적 중재와 언어치료를 제공하여 말언어발달을 촉진하는 것이 필요함을 제시하고 있다.

본 연구는 300 명 이상의 대단위 구개열 아동의 의료서비스와 말언어선별검사 결과를 토대로 구개열과 관련된 인구통계학적 정보 와 1 차 구개성형술 이후 아동들의 말 산출 능력을 살펴보았다는 데 의의가 있다. 구개열 관련 의료서비스의 향상이 이루어졌지만 많은 수의 구개열 아동의 말-언어발달상의 문제로 추가적인 수술과 언어 치료를 필요로 한다는 본 연구의 결과는 구개열 아동을 위한 보다 더 전문적인 언어치료와 정기적인 평가를 실시해야 할 것을 강조하 고 있다. 하지만 본 연구는 선별검사를 토대로 이루어진 후향적인 연구이고 국내 구개열 클리닉의 한 곳에서 수술과 평가를 받은 아 동들을 대상으로 진행된 연구라는 본질적인 제한점이 있기 때문에 본 연구에서 제시된 각 항목별 기술통계자료와 관련해서는 해석과 일반화에 주의를 기울여야 할 것이다. 특히 표현언어 지연 여부는 공식적인 언어평가도구나 일정량의 자발화 분석을 이용하기보다 는 부모 보고와 짧은 선별검사 동안 이루어진 아동의 반응을 토대 로 판단되었기 때문에 생활연령에 비해 뚜렷하게 지연을 보이는 경 우만 포함될 수 있도록 낮은 기준을 사용하였다. 많은 수의 구개열 아동들이 36 개월 미만에는 표현언어발달상의 지연을 보이는 점 (Hardin-Jones \& Jones, 2005)을 고려한다면 후속연구에서는 보다 더 객관적이고 심화된 자료를 토대로 표현언어상의 지연 여부를 판 단하고 조사해야 할 것이다. 구개열 아동의 말 산출 능력은 본 연구 에서 살펴본 구개열 유형뿐만 아니라 수술 이전의 결함 정도, 수술 법, 아동의 전반적인 발달 상황, 중이염, 부모의 양육태도, 조기 중 재 등 다양한 변인에 의해 영향을 받기 때문에 추후 이러한 중요 변 인의 영향 정도를 보다 더 체계적이고 종합적으로 살펴보는 연구가 필요하다. 이와 관련하여 본 연구에서는 대다수의 구개열 아동이 말 문제를 보이고, 1 차 구개성형술 이후 오직 $12 \%$ 정도의 아동들만 이 정상적인 말-언어발달을 이루었다고 판단되어 2차 구개성형술 이나 언어치료의 추가적인 권고 없이 수술 후 추적평가를 종결하였 다. 구개열 아동의 말 산출 능력과 관련된 선행연구와 본 연구의 대 상자의 관찰을 토대로 36 개월에 정상적인 말-언어발달을 보인 구개 
열 아동들의 경우 만성적인 중이염을 보이지 않았거나 높은 인지 능 력을 가졌고 부모가 일상생활에서 적극적으로 풍부한 언어자극을 주었을 것으로 사료된다. 또한 일부 아동의 경우는 12-24개월 사이 부모교육을 통한 조기 중재 프로그램에 적극적으로 참여하였다 (Ha, 2011, 2013). 후속연구에서는 구개열 아동의 말 산출 능력과 관 련된 변인을 살펴보는 것과 더불어 추가적인 수술 또는 언어치료를 필요로 하지 않고 정상적인 말-언어발달을 보인 아동들과 관련된 요인을 체계적으로 살펴봄으로써 1 차 구개성형술 이후 지속적인 말 문제를 보이는 아동의 비율을 감소시키는 데 기여해야할 것이다.

\section{REFERENCES}

Albery, E., \& Grunwell, P. (1993). Consonant articulation in different types of cleft lip and palate. In P. Grunwell, ed. Analysing cleft palate speech (pp. 83110). London: Whurr Publishers.

Bearn, D., Mildinhall, S., Murphy, T., Murray, J. J., Sell, D., Shaw, W. C., ... Sandy, J. R. (2001). Cleft lip and palate care in the United Kingdom-the Clinical Standards Advisory Group (CSAG) Study. Part 4: outcome comparisons, training, and conclusions. Cleft Palate-Craniofacial Journal, 38, $38-43$.

Chapman, K. L., Hardin-Jones, M. A., Goldstein, J. A., Halter, K. A., Havlik, R. J., \& Schulte, J. (2008). Timing of palatal surgery and speech outcome. Cleft Palate-Craniofacial Journal, 45, 297-308.

Fogh-Anderson, P. (1942). Inheritance of harelip and cleft palate. Copenhagen: Munksgaard.

Ha, S. (2011). Parent-implemented early intervention for young children with cleft palate. Korean Journal of Communication Disorders, 16, 460-477.

Ha, S. (2013). The effect of a language intervention program through parental training for young children with cleft palate. Journal of Speech-Language \& Hearing Disorders, 22, 189-212.

Ha, S. (2014). Phonological characteristics of early vocabulary in young children with cleft palate. Korean Journal of Speech Sciences, 6, 65-71.

Hardin-Jones, M. A., Brown, C. K., Van Demark, D. R., \& Morris, H. L. (1993). Long-term speech results of cleft palate patients with primary palatoplasty. Cleft Palate-Craniofacial Journal, 30, 55-63.

Hardin-Jones, M. A., Chapman, K. L., \& Schulte, J. (2003). The impact of cleft type on early vocal development in babies with cleft palate. Cleft Palate-Craniofacial Journal, 40, 453-459.

Hardin-Jones, M. A., \& Jones, D. L. (2005). Speech production of preschoolers with cleft palate. Cleft Palate-Craniofacial Journal, 42, 7-13.
Henningsson, G., Kuehn, D. P., Sell, D., Sweeney, T., Trost-Cardamone, J. E., \& Whitehill, T. L. (2009). Universal parameters for reporting speech outcomes in individuals with cleft palate. Cleft Palate-Craniofacial Journal, 45, $1-17$.

Inman, D. S., Thomas, P., Hodgkinson, P. D., \& Reid, C. A. (2005). Oro-nasal fistula development and velopharyngeal insufficiency following primary cleft palate surgery: an audit of 148 children born between 1985 and 1997. British Journal of Plastic Surgery, 58, 1051-1054.

Jackson, O., Stransky, C. A., Jawad, A. F., Basta, M., Solot, C., Cohen, M., ... LaRossa, D. (2013). The Children's Hospital of Philadelphia modification of the Furlow double-opposing Z-palatoplasty: 30-Year experience and long-term speech outcomes. Plastic and Reconstructive Surgery, 132, 613622 .

Karling, J., Larson, O., Leanderson, R., \& Henningsson, G. (1993). Speech in unilateral and bilateral cleft palate patients from Stockholm. Cleft PalateCraniofacial Journal, 30, 73-77.

Kim, M., \& Ha, S. (2013). Longitudinal study of early vocalization development in toddlers with and without cleft palate from 6 to 18 months of age. Communication Sciences \& Disorders, 18, 223-234.

Kim, Y. T., \& Shin, M. J. (2004). Urimal Test of Articulation and Phonology (U-TAP). Seoul: Hakjisa.

LaRossa, D. (2000). The state of the art in cleft palate surgery. Cleft PalateCraniofacial Journal, 37, 225-228.

McWilliams, B. J., Randall, P., LaRossa, D., Cohen, S., Yu, J., Cohen, M., \& Solot, C. (1996). Speech characteristics associated with the Furlow palatoplasty as compared with other surgical techniques. Plastic and Reconstructive Surgery, 98, 610-619.

Moon, H., \& Ha, S. (2012). Phonological development in toddlers with cleft palate and typically developing toddlers aged 12-24 months. Korean Journal of Communication Disorders, 17, 118-129.

Peterson-Falzone, S. J. (1990). A cross-sectional analysis of speech results following palatal closure. In J. Bardach \& H. L. Morris (Eds.), Multidisciplinary management of cleft lip and palate (pp. 750-757). Philadelphia, PA: WB Saunders.

Peterson-Falzone, S. J., Hardin-Jones, M. A., \& Karnell, M. P. (2001). Cleft palate speech (3rd ed.). St. Louis, MO: Mosby.

Phua, Y. S., \& de Chalain, T. (2008). Incidence of oronasal fistulae and velopharyngeal insufficiency after cleft palate repair: an audit of 211 children born between 1990 and 2004. Cleft Palate-Craniofacial Journal, 45, 172178. 
Riski, J. E., \& DeLong, E. (1984). Articulation development in children with cleft lip/palate. Cleft Palate Journal, 21, 57-64.

Shriberg, L. D., \& Kwiatkowski, J. (1982). Phonological disorders IIIA procedure for assessing severity of involvement. Journal of Speech and Hearing Disorders, 47, 256-270.

Van Demark, D. R., \& Hardin, M. A. (1985). Longitudinal evaluation of ar- ticulation and velopharyngeal competence of patients with pharyngeal flaps. Cleft Palate Journal, 22, 163-172.

Webb, A. A. C., Watts, R., Read-Ward, E., Hodgkins, J., \& Markus, A. F. (2001). Audit of a multidisciplinary approach to the care of children with unilateral and bilateral cleft lip and palate. British Journal of Oral and Maxillofacial Surgery, 39, 182-188. 
Seunghee Ha, et al. • Speech Outcomes of Children with Cleft Palate

Appendix 1. Description of each level of articulatory proficiency

\begin{tabular}{lll}
\hline 등급 & 수준 & \multicolumn{1}{c}{ 조작적 정의 } \\
\hline 1 & 정상 & 정확하고 명료한 발화 \\
2 & 미비 & 경도수준까지는 아니나 조음 1-2개의 경미한 왜곡, 혹은 조음발달을 지켜볼 필요가 있음 \\
3 & 경도 & 조음 1-2개 정도의 오류, 발달적 조음오류 위주 \\
4 & 경중도 & 자음 정확도 75\% 미만. 발달적 조음오류가 두드러짐, 혹은 보상조음 간헐적 발생, 조음문제로 인해 언어치료를 권고받았거나 \\
5 & 치료를 받고 있는 경우 \\
6 & 중도 & 자음정확도 50-75\% 수준. 조음오류 중 보상조음 오류가 있으며 두드러짐 \\
7 & 중심도 & 자음정확도 25-50\% 수준. 주의를 기울여야 낱말을 이해할 수 있음. 대부분 음소의 비음화, 조음오류. 비음 이외 정조음 가능한 \\
& 심도 & 음소가 3-4개 정도일 때 \\
& & 자음정확도 0-25\% 수준. 낱말 및 대화를 거의 알아들을 수 없음. 낱말검사 시, 정조음되는 음소의 수가 비음 이외 거의 없음 \\
\hline
\end{tabular}




\section{국문초록}

\section{1차 구개성형술 이후 구개열 아동의 말 산출 능력: 후향적 연구}

\section{하승희 ${ }^{\prime}$ 정승은 ${ }^{2}$ 문희원 $\cdot$ 고경석'}

'한림대학교 언어청각학부, 청각언어연구소, ${ }^{2}$ 서울아산병원 성형외과

배경 및 목적: 본 연구는 1 차 구개성형술 이후 구개열 아동들의 말 산출 능력을 살펴보았고 구개열 유형과 말 산출 결과와의 관계를 살 펴보았다. 방법: 본 연구는 2007-2012년 사이에 1차 구개성형술을 받고 생후 36개월까지 정기적인 말-언어선별검사를 받은 302명의 아 동들을 대상으로 36개월 선별검사결과와 외래진료기록을 토대로 후향적으로 실시되었다. 구개열 유형, 수술 시기와 같은 기본 정보를 수집하였고 2 차 구개성형술과 언어치료를 받은 아동의 비율, 경중도 이상의 과다비성과 조음 문제를 보이는 아동의 비율, 보상조음을 보이는 아동의 비율을 살펴보았다. 결과: 약 $17 \%$ 의 구개열 아동이 1 차 구개성형술이후에도 지속적으로 연인두 형성부전을 보여 2 차 구 개성형술을 받았고 $48 \%$ 정도의 아동들이 말 문제로 인해 언어치료를 받은 것으로 나타났다. 카이제곱 검정결과 구개열 유형에 따라 말 산출능력과 관련된 여러 변인들이 유의미한 차이를 보이는 것으로 나타났다. 일반적으로 구순구개열 아동이 구개열 아동보다 경중도 이상의 과다비성과 조음 문제를 보이는 비율이 더 높은 것으로 나타났다. 논의 및 결론: 본 연구는 많은 수의 구개열 아동이 1 차 구개성 형술 이후 부가적인 수술이나 언어치료가 필요한 말 문제를 보이는 것으로 나타났다. 본 연구결과는 구개열 아동을 대상으로 1 차 구개 성형술 이후 정기적인 추적 말-언어평가를 실시하고 구개열 아동을 위한 전문적인 언어치료 프로그램을 제공하는 것이 중요함을 강조 하고 있다.

핵심어: 구개열, 말 산출능력, 구개열 유형, 1차 구개성형술

\section{참고문헌}

김민영, 하승희(2013). 6-18개월 구개열 영유아와 일반 영유아의 발성 발달에 관한 종단연구. 언어청각장애연구, 18, 223-234.

김영태, 신문자(2004). 우리말 조음음운 평가 (U-TAP). 서울: 학지사

문희원, 하승희(2012). 12-24개월 구개열 유아와 일반 유아의 음운발달. 언어청각장애연구, 17, 118-129.

하승희(2011). 구개열 영유아를 위한 부모 중심 조기언어중재가 말-언어발달에 미치는 효과. 언어청각장애연구, 16, 460-477.

하승희(2013). 부모교육을 통한 언어중재프로그램 참여에 따른 구개열 영유아의 말-언어발달 비교 연구. 언어치료교육, 22, 189-212.

하승희(2014). 구개열 아동의 초기 어휘에 나타난 음운 특성 연구. 말소리와음성과학, 6, 65-71. 